\title{
Mosque Energy Performance, Part II: Monitoring of Energy End Use in a Hot-Humid Climate
}

\author{
Al-Homoud, M. S., Abdou, A.A., and Budaiwi, I. M. \\ Architectural Engineering Department \\ KFUPM, Dhahran, Saudi Arabia \\ alhomoud@kfupm.edu.sa
}

\begin{abstract}
In regions with harsh climatic conditions mosques, like other buildings, have to be mechanically air-conditioned in order to achieve the desired thermal conditions. However, mosques are characterized by a unique intermittent operation schedule as compared to typical types of buildings. Within a given region and time zone, mosques are operated at the same time. This could have an impact on the demand for energy particularly in areas with high demand for air-conditioning and/or heating that frequently coincides with peak energy demand periods. Monitoring of building energy is a practical tool for providing realistic and empirical field data that represent actual building energy performance and quantify changes over time. Monitoring helps in segregating energy uses over time and in assessing the thermal performance of buildings subject to alternative design and operating strategies. In this study, energy uses of a representative sample of five typical mosques were monitored for a twoyear period. Energy use records were measured utilizing 5-minute and 1hour intervals in order to establish the actual intermittent operating profile for mosques. This study is part II of a comprehensive investigation of mosque energy systems, overall thermal performance and operation strategies. It summarizes the analysis and results of monitored energy use data for different types of typical mosques in the hot-humid climate of the eastern region of Saudi Arabia. The monitored data were analyzed and compared to long-term (5-year) average electric energy utility bills data.
\end{abstract}

KEYWORDS: Energy use, mosques, monitoring, utility bills.

\section{Introduction}

Mosques represent the central location in which people gather for their daily as well as weekly prayers. The mosque is also considered an educational, cultural, and social center for Muslims' activities. In regions with harsh climatic 
conditions such as those of Saudi Arabia, in order to achieve the desired thermal conditions, mosques require mechanical air-conditioning. However, mosques are characterized by having a unique intermittent operation schedule as compared to other types of buildings. Within a given region and time zone, they are operated at the same time. This could have an impact on the demand for energy particularly in areas with high demand for air-conditioning and/or heating that frequently coincides with peak energy demand periods. These factors and the necessity for performing prayers in a comfortable environment make the thermal design and operation of mosques very important. The literature lacks adequate research on the thermal design and energy performance of mosques, in spite of the fact that these areas could provide information invaluable to designers and engineers as well as those involved in the operation and maintenance of mosques.

The demand for energy in mosques in particular can be critical as they are all operated at almost the same time of the day in each region of the kingdom, especially at the times of Dhuhr (noon) and Asr (afternoon) prayers, which fall within the most critical demand periods in summer. Research on the thermal design and energy use of mosques been very limited [1]. Therefore, in-depth studies of mosques thermal performance and energy use are highly needed especially in Saudi Arabia, where a large number of mosques are already being operated and many more are expected to be built in the future.

A sample of representative mosques was selected and surveyed. Monthly electric energy bills data for five years were obtained and analyzed for the selected sample mosques as presented in an earlier study [1]. The analyses of electric energy bills data were found useful in showing the general trend and the history of energy use for those mosques. The billing data can provide a reasonable estimate of the overall annual electric energy use for each mosque. However, electric energy billing data does not provide the necessary level of accuracy as well as the needed segregated end energy uses by the various energy systems for the purpose of detailed energy analysis. Therefore, a more accurate and detailed approach of investigating energy use in buildings is through energy monitoring. The monitoring data are more useful in determining segregated energy flow and pattern of use over time.

\section{Energy Monitoring}

Building energy monitoring is a practical tool for providing realistic and empirical field data that represent actual building energy performance and quantify changes over time. The objectives of building energy monitoring can be summarized as follows [2]: 1. Determination of the characteristics of specific energy end uses in a building; 2. Assessment of the performance of building 
energy system technology or retrofit measures; 3 . Measurement and verification of building energy savings; 4 . Diagnosis of the physical or operational related problems of building energy.

For the purpose of this study, monitoring of the energy of sample mosques was undertaken to achieve a combination of the above-mentioned objectives. The major emphasis was to determine the characteristics of the actual energy end uses in the mosque and their trends over time. The ultimate goal is to assess the thermal performance of mosques subject to alternative design and operating strategies through energy simulation calibrated using actual measured data. The five mosques, namely, Owais Al-Qarni, Al-Humaidi, Al-Bukhari, Abu-Ubaidah, and Al-Doha mosque, were monitored for a two-year period. For the first five months of monitoring starting July 2000, end use energy measurements were recorded every five minutes. The main objective for the acquisition of such short time periods of records was to establish the actual operating profile for mosques as they are subject to different daily intermittent occupancies. For practical reasons, mosque energy uses were then monitored on an hourly basis for the remaining period.

\section{Mosque Energy Monitoring}

The selection of the proper monitoring equipment is an important issue in the measurement of energy end uses. After a careful search for energy monitoring equipment, the "Elitepro" energy data logger [3] was selected for measuring energy uses in the selected mosques. In order to test the equipment and set the appropriate monitoring time interval, the data logger was installed in Abu-Ubaidah mosque. Considering the intermittent occupancy of mosques, energy use monitoring was initially set at a one-minute interval data acquisition for two successive days. Fig. 1(a) illustrates the pattern of base-load energy use in the daily cycle with peak load of lighting usage at the five daily prayer times during the two days of Thursday and Friday. Air-conditioning units were not operating during this monitoring period. As can be seen from part (a) of Fig. 1 the fine resolution of the acquisition made it difficult to observe the energy usage pattern represented by the envelope fluctuations.

The data acquisition interval was then modified from one minute to five minutes. Fig. 1(b) shows the monitored base-load energy use for a weekday. The energy use pattern can be better observed and interpreted with a 5-minute interval acquisition with less data to be managed. In order to test the operation of the data logger for an extended period of time, the daily pattern of electric energy use was monitored for six successive weekdays. Fig. 1(c) illustrates the energy use patterns superimposed. The consistency of daily peak base-load occurrence time, duration and magnitude verifies the consistent operation and 
data acquisition of the monitoring equipment.
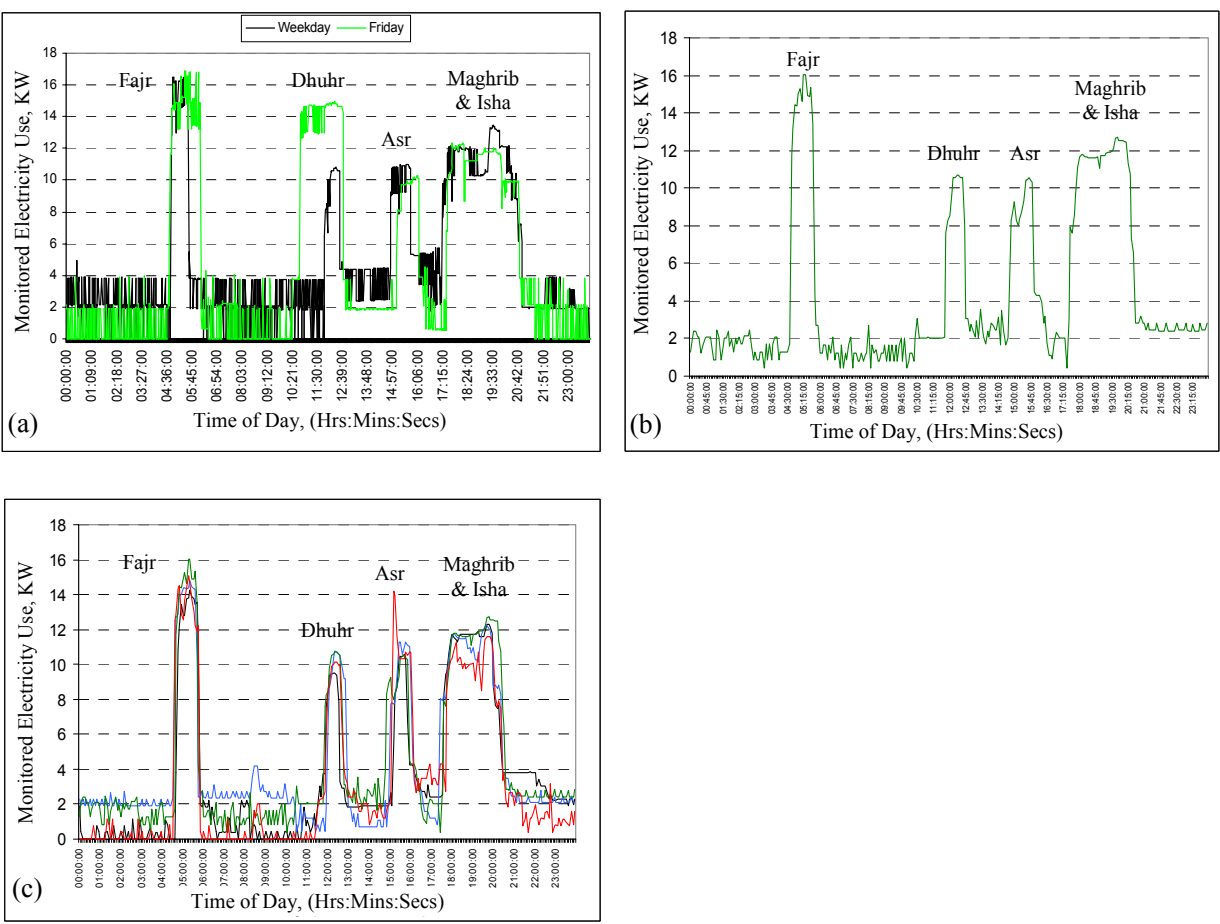

Fig. 1: (a) The patterns of monitored electric energy use (kW) of Abu-Ubaidah mosque (superimposed) for a weekday and Friday acquired using a 1-minute interval, (b) using a 5-miunte interval, and (c) using a 5-minute interval, for six successive weekdays.

Having tested the energy monitoring equipment and set the appropriate data acquisition time interval for establishing actual mosque occupancy, energy data loggers were installed in the investigated mosques. For practical and economic reasons, it was not possible to conduct detailed energy monitoring (segregated $\mathrm{A} / \mathrm{C}$, lighting, and fans) for all five mosques. Detailed measurements were conducted for three of the five mosques (i.e. Al-Humaidi, Owais Al-Qarni, and $A l$-Bukhari) while overall energy monitoring was performed for the other two mosques of Abu-Ubaidah and Al-Doha.

\subsection{Establishing Mosque Occupancy Time Periods}

In buildings such as mosques that are characterized by daily intermittent occupancies, it is very important to relate the use of $\mathrm{A} / \mathrm{C}$, lighting and ceiling fans to occupancy patterns during the Daily and Friday prayers. For example, in 
order to relate these uses to occupancy, the prayers' Azan (call for prayers) times were obtained at the start and the end of August 2001 for the eastern region of Saudi Arabia (represented by Dammam City). It is known that the Azan times change from the start to the end of each month year round based on the lunar calendar. Additionally, expected occupancy time differs considering the "Iqama" time (actual start time for performing prayer) which in turn varies from one prayer to the other during the day. The typical "Iqama" period for each prayer was assumed to be 30,20,20, 10, and 20 minutes after Azan time for Fajr (dawn), Dhuhr (noon), Asr (afternoon), Maghrib (sunset), and Isha (evening) prayers, respectively. The expected typical worshipper's stay to perform each prayer was assumed to be 15 minutes. Therefore, it was possible to obtain the start and end limits of the mosque daily expected Occupancy Time Periods (OTP) over the whole month. Table 1 shows the Azan call times for the month of August 2001 both at the start (August 1) and at the end (August 31) "Iqama" time after Azan and the expected occupancy periods from "Iqama" period. The overall expected OTPs start and end limits during the whole month are then determined for each daily prayer as given in Table 1 .

Table 1: Example of expected OTP during the month of August [on August 1, and August 31].

\begin{tabular}{|c|c|c|c|c|c|c|c|c|c|c|}
\hline \multirow[t]{2}{*}{ Prayer } & \multicolumn{2}{|c|}{$\begin{array}{l}\text { Prayer Call } \\
\text { Time } \\
\text { (Hrs: Mins) }\end{array}$} & \multicolumn{3}{|c|}{$\begin{array}{c}\text { Occupancy Time Period } \\
\text { OTP }\end{array}$} & \multicolumn{2}{|c|}{$\begin{array}{l}\text { OTP End Time } \\
\text { (Hrs: Mins) }\end{array}$} & \multicolumn{2}{|c|}{$\begin{array}{c}\text { OTP Time } \\
\text { Limits over the } \\
\text { month } \\
\text { (Hrs: } \text { Mins) }\end{array}$} & \multirow[b]{2}{*}{$\begin{array}{c}\text { Difference } \\
\text { Over the } \\
\text { month } \\
\text { (Mins) }\end{array}$} \\
\hline & $\begin{array}{c}\text { Start } \\
\text { of } \\
\text { August }\end{array}$ & $\begin{array}{c}\text { End } \\
\text { of } \\
\text { August }\end{array}$ & $\begin{array}{c}I Q A M A \\
\text { period } \\
\text { after Athan } \\
\text { (Mins) }\end{array}$ & $\begin{array}{l}\text { Stay time } \\
\text { after } \\
I Q A M A \\
\text { (Mins) }\end{array}$ & $\begin{array}{c}\text { OTP } \\
\text { from } \\
\text { Athan } \\
\text { (Mins) }\end{array}$ & $\begin{array}{c}\text { Start } \\
\text { of } \\
\text { August }\end{array}$ & $\begin{array}{l}\text { End } \\
\text { of } \\
\text { August }\end{array}$ & $\begin{array}{l}\text { Start } \\
\text { Limit }\end{array}$ & $\begin{array}{c}\text { End } \\
\text { Limit }\end{array}$ & \\
\hline Fajr & $03: 35$ & $03: 56$ & 30 & 15 & 45 & $04: 20$ & $04: 41$ & 03:35 & 04:41 & 66 \\
\hline Dhuhr & $11: 46$ & $11: 40$ & 20 & 15 & 35 & $12: 21$ & $12: 15$ & $11: 40$ & $12: 21$ & 41 \\
\hline Asr & $15: 16$ & $15: 11$ & 20 & 15 & 35 & $15: 51$ & $15: 46$ & $15: 11$ & $15: 51$ & 40 \\
\hline Maghrib & $18: 27$ & 18:01 & 10 & 15 & 25 & $18: 52$ & $18: 26$ & 18:01 & $18: 52$ & 51 \\
\hline Isha & $19: 57$ & $19: 31$ & 20 & 15 & 35 & $20: 32$ & 20:06 & 19:31 & $20: 32$ & 61 \\
\hline
\end{tabular}

Accordingly, the time start and end limits of the typical mosque use periods, during the month of August for the Dammam area, are graphically represented as shown in Fig. 2. The shaded bars represent the expected occupancy periods (OTPs) at the start of the month while the void bars indicate the same but at the end of the month. The shift of OTP for Fajr (dawn), Maghrib (sunset) and Isha (evening) prayers can be visually identified. 


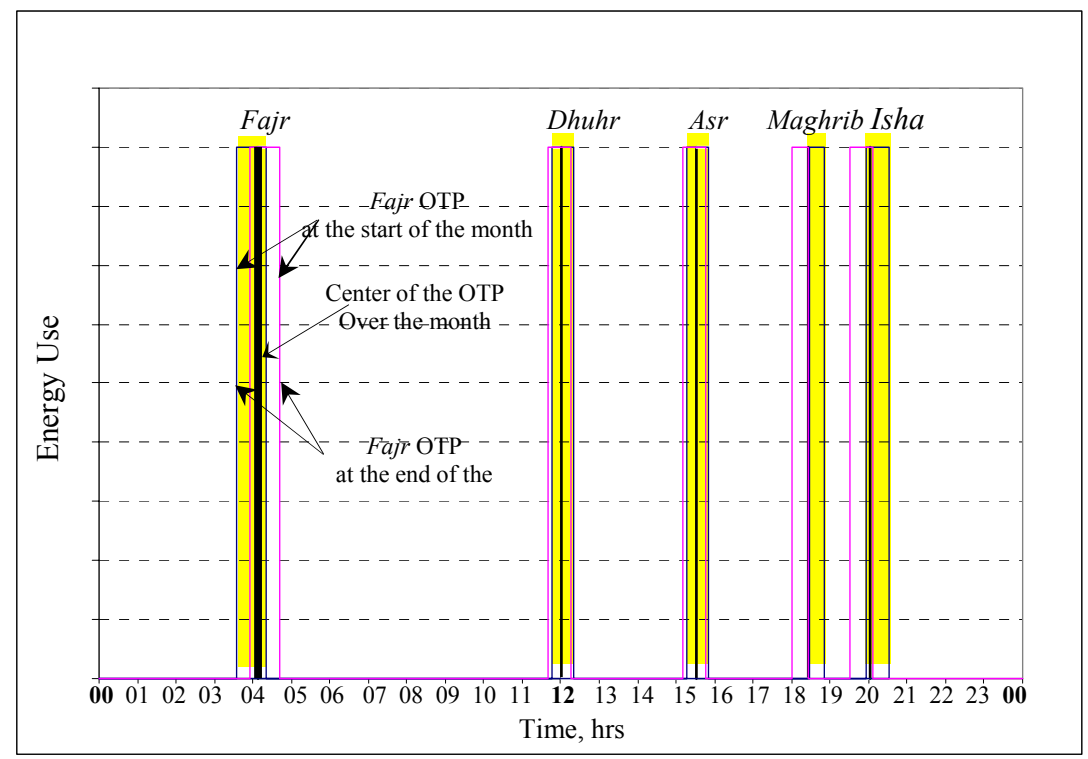

Fig. 2: Mosque expected occupancy time periods (OTP) during the month of August for Dammam City

Plotting the measured energy use data overlaid on the graphical template of Fig. 2 would then reveal the corresponding usage pattern (operation) of the mosque's A/C system and how well or otherwise it coincides with the expected OTP. Monitoring of the different mosque energy systems utilizing 5-minute intervals will reveal the actual operation of those systems. For example, Fig. 3 depicts the actual daily pattern of energy used by the A/C system in Al-Humaidi mosque during the days of August 2001. The events of operating the $\mathrm{A} / \mathrm{C}$ closely coincide with the expected OTP on many but not all days of the month. As can be seen from the figure, on some days the $\mathrm{A} / \mathrm{C}$ was left operating between Fajr and Dhuhr prayers and in between other prayer times as well. The profile highlighted in bold represents the average energy use pattern over the whole month of August 2001. As noticed in Fig. 3 (and later Fig. 4), the x-axis is labeled "Data record number". This number refers to the 5-minute recording period which yields 12 recording periods for every hour. The corresponding value on the y-axis represents the average energy use $(\mathrm{kWh})$ over the 5-minute interval (i.e. $\mathrm{kW} \times 5 / 60$ ). The corresponding time of the day is also shown on the $\mathrm{x}$-axis on top of the graph to make it easier to relate energy use to prayer times over the day. The OTP for each prayer is shaded in the graph background. A similar approach was followed to determine standard as well as actual monthly OTPs for all investigated mosques. 
Time, Hrs

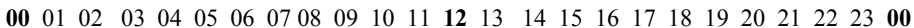

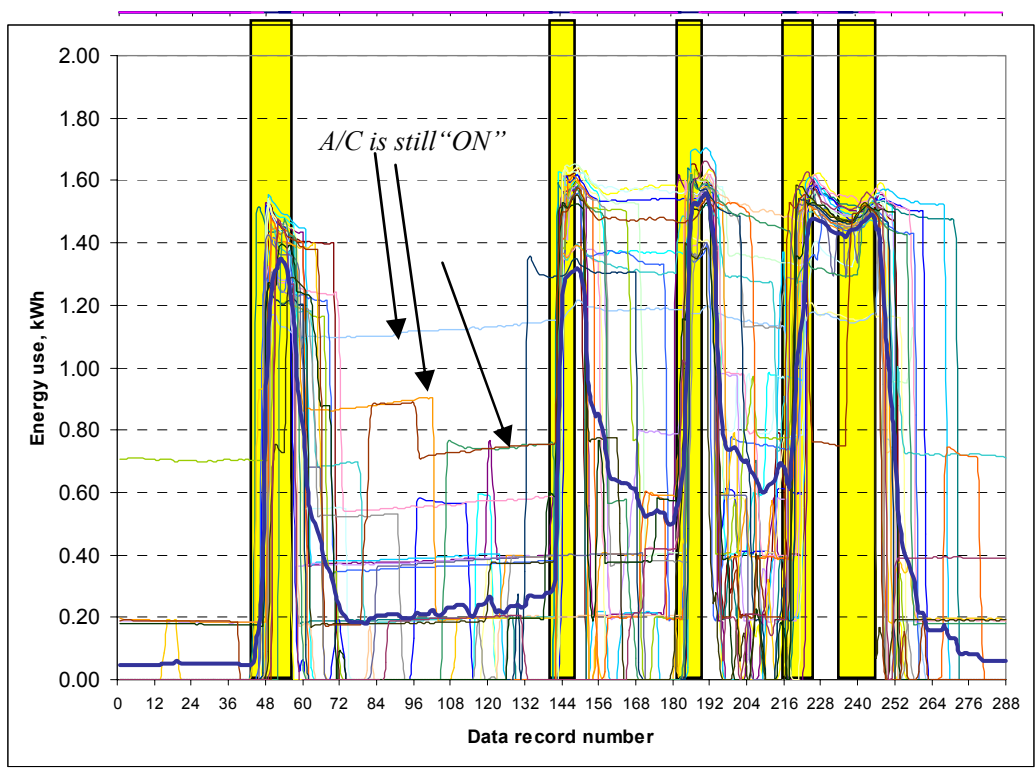

Fig. 3: The daily energy usage profile of the A/C system during August 2001 for $\mathrm{Al}$ Humaidi mosque. Average profile of data records is represented by a bold line.

Fig. 4(a) shows the same presentation but for the actual operation pattern of the lighting system for the same mosque. Lights were left "ON" either fully or partially in between prayer times more frequently than the $\mathrm{A} / \mathrm{C}$ system. Fig. 4(b) depicts the average of the energy used by the ceiling fans in the same mosque. From the measured data sample, presentation and analysis of the daily usage in terms of magnitude and patterns one would get a sense of how each system of energy is commonly operated and its relative contribution to the total energy use. The average profiles of $\mathrm{A} / \mathrm{C}$, lighting and ceiling fans are shown in Fig. 4(c) in relation to the expected OTP.

\section{Analysis of Mosque Monitored Energy Use Data}

Al-Humaidi mosque was initially selected to represent small size mosques for daily prayers. It was monitored in detail and used as a base case for detailed analysis as presented earlier for establishing mosque OTP and energy use profiles. However, this mosque was subjected to major modifications including the addition of a second floor and new lighting system. These changes meant the mosque could no longer be classified as a typical small size mosque. Therefore, energy monitoring was terminated for this particular mosque after records of data had been collected for one year. 

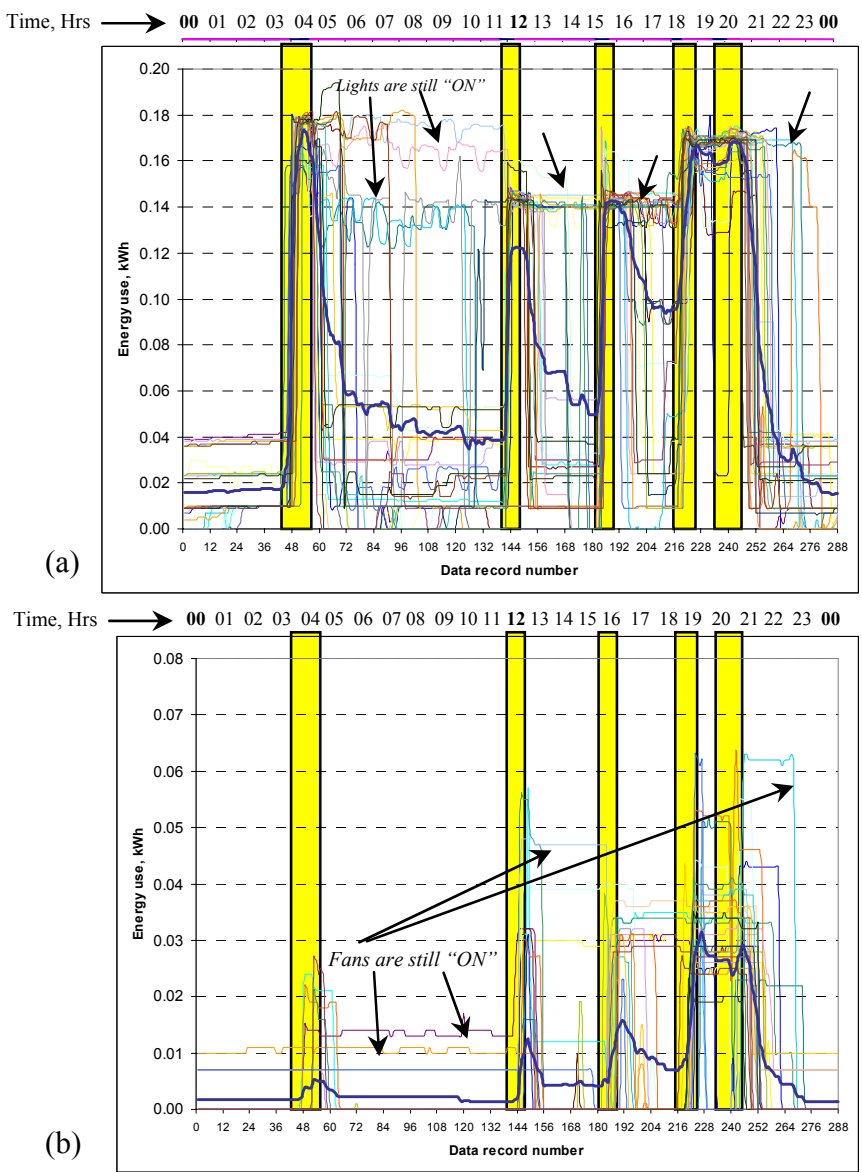

Time, Hrs $\longrightarrow 00010203040506070809101112131415161718192021222300$

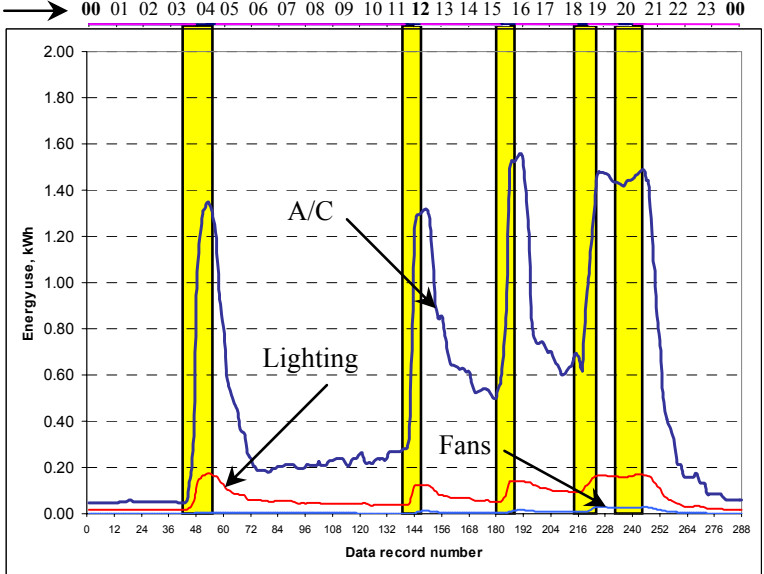

Fig. 4: The daily energy usage profile of (a) the lighting system, (b) ceiling fans, and (c) Average energy use profiles of the $\mathrm{A} / \mathrm{C}$, lighting and ceiling fans during August 2001 for Al-Humaidi mosque. Average profile of data records is represented by a bold line. 
Furthermore, due to the size and redundancy of data acquired for 5-minute intervals after establishing the trend of mosque usage and occupancy profiles, energy monitoring for the remaining period of the year 2002 onwards was conducted on an hourly basis for the other four monitored mosques. Monitored mosque electric energy use data for the full twelve months of the year 2002 (except Al-Humaidi mosque, 2001-2002) are shown in Figs. 5(a) to 5(e) for the five mosques. For the first three mosques of Owais Al-Qarni, Al-Humaidi and Al-Bukhari, detailed (segregated) monthly energy data are presented while mosque overall monthly energy uses are presented for the other two i.e. $A b u$ Ubaidah and Al-Doha mosques.

Table 2 summarizes a comparative energy end uses data for the monitored mosques. From the analysis of the segregated energy use data for the three mosques of Owais Al-Qarni, Al-Humaidi, and Al-Bukhari, it is observed that $\mathrm{A} / \mathrm{C}$ is clearly the most energy using system representing $79.34 \%, 69.8 \%$ and $70.6 \%$ of the yearly total energy use for the three mosques, respectively with an average of $73.3 \%$. While Al-Humaidi and Al-Bukhari mosques, located in AlKhobar, have similar percentages of energy use by the A/C system (about $70 \%$ ), Owais Al-Qarni mosque, located in Dammam, has a higher share of energy for the A/C system amounting to $79 \%$ of the yearly total. The climatic conditions for Dammam and Al-Khobar are similar and, therefore, the difference in the percentage of energy use for A/C, 9\% more for Owais Al-Qarni, can be attributed to many factors notable among them being the differences in the physical and operational parameters among those mosques.

For all investigated mosques, it is observed that $\mathrm{A} / \mathrm{C}$ is operating from March to November with its peak use during summer months. The total energy use, then, follows the profile of the $\mathrm{A} / \mathrm{C}$ system, the major energy consuming system with relatively steady and small use by lighting followed by ceiling fans for all months. This confirms the influence of A/C systems on energy use which dominates during summer and then sets the energy use trend for the whole year. The same overall energy use profile applies to the other two mosques of $A b u$ Ubaidah and Al-Doha with whole energy monitored data as presented in Figs. 5(d) and 5(e), respectively.

The lighting system contributes $17.32 \%, 20.7 \%$, and $27.3 \%$, of the annual total energy use for the same three mosques, respectively with an average of $21.8 \%$. Comparing these percentages to the energy use trends for the same systems as presented in the monthly data of Figs. 5(a) to 5(e) shows that while the weather dependent $\mathrm{A} / \mathrm{C}$ system energy use varies with the season, the lighting system energy use shows a relatively steady profile over the year as expected. 


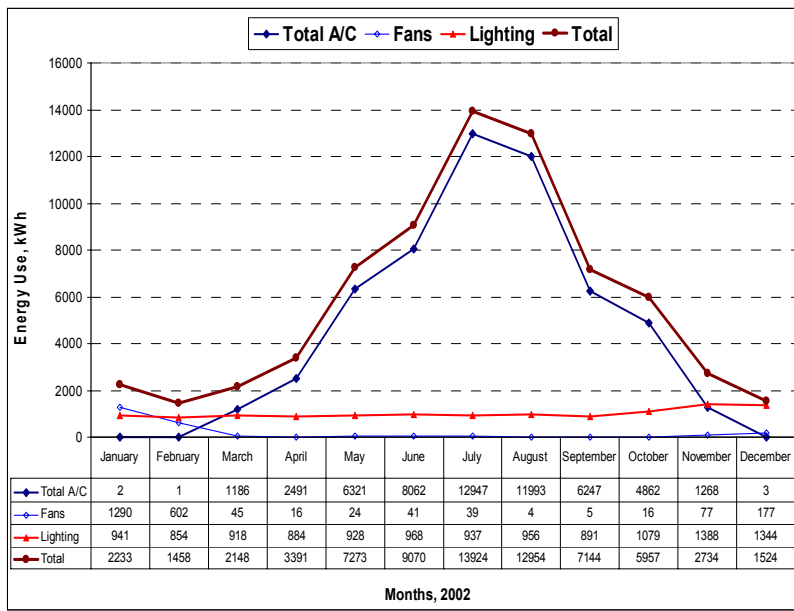

(a)

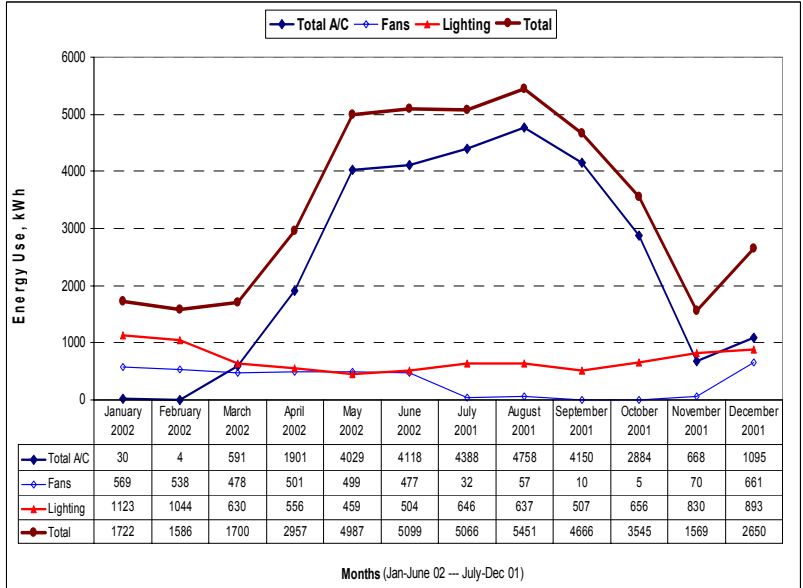

\begin{tabular}{|l|c|c|c|}
\cline { 2 - 4 } \multicolumn{1}{c|}{} & TOTAL & $\%$ & $\mathbf{k W h} / \mathbf{m}^{2} . \mathbf{y r}$ \\
\hline A/C & 55384 & 79.34 & 147.7 \\
\hline Fans & 2336 & 3.35 & 6.2 \\
\hline Lighting & 12089 & 17.32 & 32.2 \\
\hline Total & $\mathbf{6 9 8 0 9}$ & $\mathbf{1 0 0 . 0 0}$ & $\mathbf{1 8 6 . 2}$ \\
\hline
\end{tabular}

(b)

\begin{tabular}{|l|c|c|c|}
\cline { 2 - 4 } \multicolumn{1}{c|}{} & TOTAL & $\%$ & $\mathrm{kWh} / \mathbf{m}^{2} . \mathbf{y r}$ \\
\hline A/C & 28617 & 69.8 & 157.2 \\
\hline Fans & 3896 & 9.5 & 21.4 \\
\hline Lighting & 8484 & 20.7 & 46.6 \\
\hline Total & $\mathbf{4 0 9 9 7}$ & $\mathbf{1 0 0 . 0}$ & $\mathbf{2 2 5 . 3}$ \\
\hline
\end{tabular}

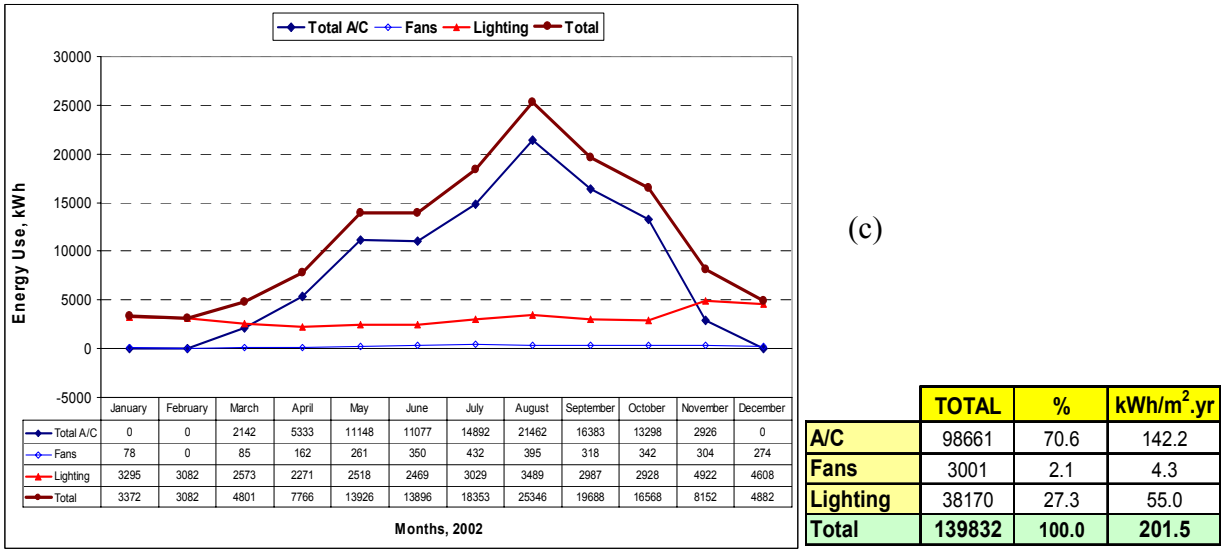

Fig.5: Monitored energy use for the year 2002 of (a) Owais Al-Qarni mosque, (b) AlHumaidi mosque for the period January-June 2002 and July-December 2001, and (c) Al-Bukhari mosque. 


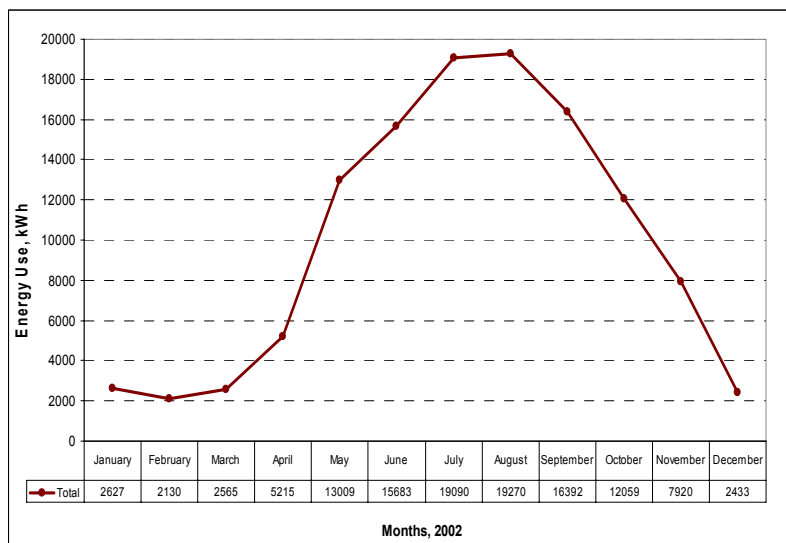

(d)

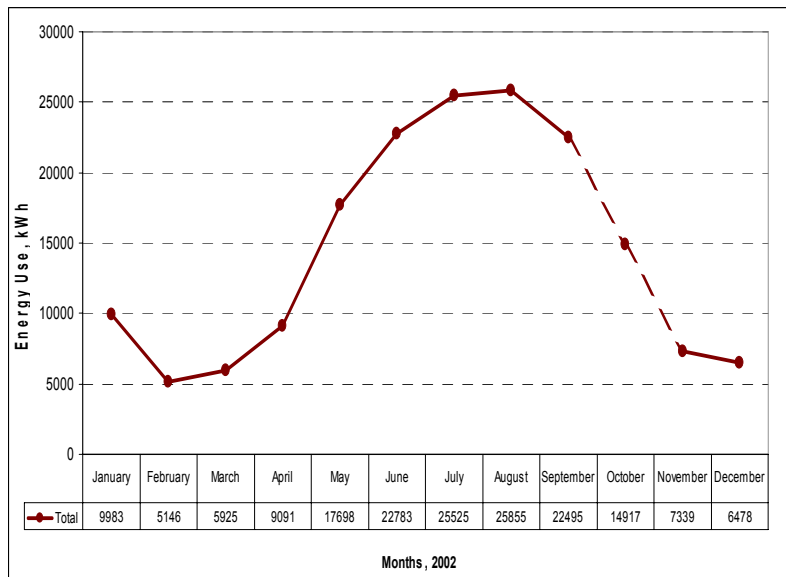

\begin{tabular}{|c|c|c|c|}
\cline { 2 - 4 } \multicolumn{1}{c|}{} & TOTAL & $\%$ & $\mathrm{kWh} / \mathrm{m}^{2} . \mathrm{yr}$ \\
\hline Total & 118393 & 100.0 & 93.5 \\
\hline
\end{tabular}

Fig.5: (Continued), Monitored energy use for the year 2002 of (d) Abu-Ubaidah AlJarrah mosque, and (e) Al-Doha mosque.

Table 2: The monitored segregated energy end use of the investigated mosques.

\begin{tabular}{|l|l|l|l|c|c|c|c|c|}
\hline \multirow{2}{*}{ Mosque Name } & \multicolumn{1}{|c|}{$\begin{array}{c}\text { Mosque } \\
\text { Location }\end{array}$} & \multicolumn{1}{|c|}{$\begin{array}{c}\text { Mosque } \\
\text { Type }\end{array}$} & $\begin{array}{c}\text { Mosque } \\
\text { A/CArea } \\
\left(\mathrm{m}^{2}\right)\end{array}$ & $\begin{array}{c}\text { Annual } \\
\text { Energy Use }\end{array}$ & $\begin{array}{c}\text { Annual } \\
\text { Energy } \\
\text { Use } \\
\text { Index } \\
\left(\mathrm{Kwh} / \mathrm{m}^{2}\right)\end{array}$ & \multicolumn{4}{|c|}{$\begin{array}{c}\text { Segregated End } \\
\text { Energy Use } \\
\%\end{array}$} & $\begin{array}{c}\text { Lighting } \\
\%\end{array}$ & $\begin{array}{c}\text { Fans } \\
\%\end{array}$ \\
\hline Owais Al-Qarni & Dammam & Daily & 375 & $\mathbf{6 9 8 0 9}$ & $\mathbf{1 8 6 . 2}$ & $\mathbf{7 9 . 3 4}$ & $\mathbf{1 7 . 3 2}$ & $\mathbf{3 . 3 5}$ \\
\hline Al-Humaidi & Thuqbah & Daily & 182 & $\mathbf{4 0 9 9 7}$ & $\mathbf{2 2 5 . 3}$ & $\mathbf{6 9 . 8}$ & $\mathbf{2 0 . 7}$ & 9.5 \\
\hline Al-Bukhari & Al-Khobar & Daily/Friday & 694 & $\mathbf{1 3 9 8 3 2}$ & $\mathbf{2 0 1 . 5}$ & $\mathbf{7 0 . 6}$ & $\mathbf{2 7 . 3}$ & $\mathbf{2 . 1}$ \\
\hline Abu-Ubaidah & Al-Thuqbah & Daily/Friday & 1266 & $\mathbf{1 1 8 3 9 3}$ & $\mathbf{9 3 . 5}$ & & NA \\
\hline Al-Doha & Dhahran & Daily/Friday & 854 & $\mathbf{1 7 3 2 3 4}$ & $\mathbf{2 0 2 . 9}$ & & \multicolumn{2}{|c|}{ NA } \\
\hline
\end{tabular}


Ceiling fans on the other hand contribute a much smaller amount of energy over the year with $3.35 \%, 9.5 \%$, and $2.1 \%$ of the annual total energy use for the three mosques resulting in an average of $5 \%$ for the same three mosques, respectively. However, the energy use by fans is not consistent for all mosques throughout the year. For example, it shows an increase during the winter months of December, January, and February for Owais Al-Qarni mosque as presented in Fig. 5(a), which can be attributed to the need for air movement to overcome stagnation of air and the latent heat generation during prayer times without the need for using the $\mathrm{A} / \mathrm{C}$ system during such colder (winter) months. During these same months $\mathrm{A} / \mathrm{C}$ energy use is negligible (almost zero) where fans are relied upon for achieving air movement in addition to any other available means such as opening windows and doors for natural ventilation. This mosque is noted not to have full or even half of its capacity at any prayer time.

Al-Humaidi mosque energy use presented in Fig. 5(b), on the other hand, shows much more energy use $(9.5 \%)$ for ceiling fans than the other two mosques year round. The presented data extends between the years 2001 and 2002 monitoring period. From examining the presented data, it is observed that most of this energy use by fans occurs during the period between the months of December and June with a drop in use for the period from July to November. This shows more reliance on ceiling fans during winter months as well as inbetween season periods especially before summer. This can be attributed to the inefficiency of the available $\mathrm{A} / \mathrm{C}$ system and the need for air movement in this mosque using fans. This might be due to the heavy latent load from worshippers as this mosque is always fully occupied during most of the daily prayers because of its location downtown in a main commercial street as opposed to the less heavily populated locations of the other mosques.

Al-Bukhari mosque data presented in Fig. 5(c) show almost steady energy use by fans over the year with the minimum use during the winter months of January and February during which $\mathrm{A} / \mathrm{C}$ use is zero. Although energy use by fans in all mosques does not show a clear and consistent trend, it is so low that a definite conclusion can not be drawn with the exception that it is needed to supplement $\mathrm{A} / \mathrm{C}$ in air movement during summer months. Fans are also relied on during other non-summer months especially when the mosque is fully occupied and/or the $\mathrm{A} / \mathrm{C}$ system is not as efficient as it should be.

From the analyses of the mosques energy use monitored data, it is clear that $\mathrm{A} / \mathrm{C}$ system is the single most energy intensive system in the mosque as is the case in many other buildings in hot-humid climates. Therefore, it requires careful design and operation in order to achieve the required thermal comfort at the least energy requirements. The lighting system, although it requires much 
less energy than $\mathrm{A} / \mathrm{C}$, accounts for steady energy use year round and needs to be designed and operated efficiently. In addition, means should also be provided in the design of mosques to allow for providing natural ventilation for the worshippers during winter and in-between season periods.

Comparing the monitored annual energy use indices for the five mosques shows differences among them as summarized in Table 3. The highest annual energy use index observed is for Al-Humaidi mosque $\left(225.3 \mathrm{kWh} / \mathrm{m}^{2} . \mathrm{yr}\right)$, with the lowest reported for $A b u$-Ubaidah mosque of $93.5 \mathrm{kWh} / \mathrm{m}^{2} . \mathrm{yr}$ resulting in a maximum difference $131.8 \mathrm{kWh} / \mathrm{m}^{2}$.yr (58.5\%). However, Al-Humaidi and $A b u$-Ubaidah mosques are observed to represent two extremes in energy use with the smallest and largest mosques in the group having the high and low sides of energy use indices of 225.3 and $93 \mathrm{kWh} / \mathrm{m}^{2}$, respectively. The average annual energy use index for all five mosques is $181.9 \mathrm{kWh} / \mathrm{m}^{2} . \mathrm{yr}$.

Table 3: The monitored segregated energy end use of the investigated mosques.

\begin{tabular}{|c|c|c|c|c|c|c|c|c|}
\hline \multirow{2}{*}{ Mosque Name } & \multirow{2}{*}{$\begin{array}{l}\text { Mosque } \\
\text { Location }\end{array}$} & \multirow{2}{*}{$\begin{array}{l}\text { Mosque } \\
\text { Type }\end{array}$} & \multirow{2}{*}{$\begin{array}{c}\text { Mosque } \\
\text { A/C } \\
\text { Area } \\
\left(\mathrm{m}^{2}\right)\end{array}$} & \multirow{2}{*}{$\begin{array}{c}\text { Annual } \\
\text { Energy } \\
\text { Use } \\
(\mathrm{kWh})\end{array}$} & \multirow{2}{*}{$\begin{array}{c}\text { Annual } \\
\text { Energy } \\
\text { Use Index } \\
\left(\mathrm{Kwh} / \mathrm{m}^{2}\right)\end{array}$} & \multicolumn{3}{|c|}{$\begin{array}{l}\text { Segregated End } \\
\text { Energy Use }\end{array}$} \\
\hline & & & & & & $\begin{array}{l}\mathrm{A} / \mathrm{C} \\
\% \\
\end{array}$ & $\begin{array}{c}\text { Lighting } \\
\%\end{array}$ & $\begin{array}{c}\text { Fans } \\
\%\end{array}$ \\
\hline Owais Al-Qarni & Dammam & Daily & 375 & 69809 & 186.2 & 79.34 & 17.32 & 3.35 \\
\hline Al-Humaidi & Thuqbah & Daily & 182 & 40997 & 225.3 & 69.8 & 20.7 & 9.5 \\
\hline Al-Bukhari & Al-Khobar & Daily/Friday & 694 & 139832 & 201.5 & 70.6 & 27.3 & 2.1 \\
\hline Abu-Ubaidah & Al-Thuqbah & Daily/Friday & 1266 & 118393 & 93.5 & \multicolumn{3}{|c|}{ NA } \\
\hline Al-Doha & Dhahran & Daily/Friday & 854 & 173234 & 202.9 & \multicolumn{3}{|c|}{ NA } \\
\hline & & & & Average & 181.9 & 73.3 & 21.8 & 5 \\
\hline
\end{tabular}

The high-energy use for Al-Humaidi mosque can be attributed to the fact that it is an old small mosque located in a busy commercial downtown street with full occupancy most of the prayer times. This results in a greater use of its window air-conditioning units to achieve thermal comfort while most of these units are old and not functioning well. This might also explain the frequent use of ceiling fans in the mosque compared to the other mosques as discussed earlier. This mosque was also subjected to major modifications during the monitoring process. The first started on November 2001 with the addition of a new lighting system to the main prayer area of the mosque. This can be observed in the increase of lighting energy use and the accompanying increase in the A/C system energy use as well at this month as presented in Fig. 5(b). The second major modification to the mosque started in March 2002 with the addition of a second floor to the mosque, which was not mechanically airconditioned until a later stage. 
The low energy use index of the Abu-Ubaidah, on the other hand, can be attributed to a number of different reasons including its new construction and the relatively large area (compared to the other mosques) while only a small portion (always partially occupied) of that area of the mosque is utilized (airconditioned) during daily prayers resulting in a smaller energy use per unit area. In addition, it is the only mosque among the investigated group which is known to have wall and roof thermal insulation. This fact indicates the strong dependency of mosques energy use on the outside weather conditions and the importance of envelope design and construction in saving energy needed to aircondition mosques.

Excluding Al-Humaidi and Abu-Ubaidah mosques from the comparison at this point will bring the difference in the annual energy use index among the other three mosques to within $8.2 \%\left(16.7 \mathrm{kWh} / \mathrm{m}^{2} . \mathrm{yr}\right)$. The average annual energy use index of these three mosques is $196.9 \mathrm{kWh} / \mathrm{m}^{2}$.yr. This average can be said to represent most typical mosques in the area. The values of 225.3 $\mathrm{kWh} / \mathrm{m}^{2}$.yr for Al-Humaidi mosque and $93.5 \mathrm{kWh} / \mathrm{m}^{2}$.yr for Abu-Ubaidah mosque can be said to represent the other types of old, small and crowded mosques and the newly constructed insulated large mosques, respectively. The year 2002 monitored energy use indices $\left(\mathrm{kWh} / \mathrm{m}^{2} . \mathrm{yr}\right)$ for the five mosques are presented in Fig. 6. The average for the five mosques is also shown. The presented results illustrate the magnitude of the variations in the annual energy use indices among the different mosques and that of Abu-Ubadiah mosque in particular due to the above-mentioned reasons.

\section{Comparison of Measured and Billed Energy Data of Mosques}

The analysis of five-year electric energy billing data for the investigated mosques was presented in an earlier study [8]. Comparison of the monitored and billed energy uses and indices for the same are presented in Table 4. The 2002 monitored electric energy use data are shown to be within $12.6 \%$ of the 5year average billing data for the four mosques of Owais Al-Qarni, Al-Bukhari, Abu-Ubaidah, and Al-Doha. Values for Al-Humaidi mosque represent the twelve month monitored data for two overlapping years for the period from July 2001 to June 2002. Including the data for this mosque will bring the difference in monitored and 5-year billing data for all mosques to $15.5 \%$. Monitored values are observed to be higher than the 5-year billing data average for all mosques except Owais Al-Qarni (4\% less). This shows a reasonable agreement considering the changes in weather conditions from one year to another as well as the expected changes in the operation of the different mosques from one time to another. The 5-year annual average energy use index for all mosques is 171 $\mathrm{kWh} / \mathrm{m}^{2}$.yr compared to $181.9 \mathrm{kWh} / \mathrm{m}^{2}$.yr for the 2002 monitored data $(6.4 \%$ difference). The reasonably close agreement between the monitored electric 
energy data of the mosques and the longer term 5-year average values confirms the general trends in energy use over time by all mosques under investigation as discussed earlier. The year 2002 monitored energy use indices $\left(\mathrm{kWh} / \mathrm{m}^{2} . \mathrm{yr}\right)$ compared to the 5-year average for the five mosques are presented in Fig. 6. The averages of the five mosques are shown.

Table 4: Monitored energy use (2002) vs. 5-year (1998-2002) average electric utility billing data.

\begin{tabular}{|c|c|c|c|c|c|}
\hline \multirow{2}{*}{ Mosque Name } & \multicolumn{2}{|c|}{$\begin{array}{c}\text { Annual Energy Use } \\
(\mathrm{kWh})\end{array}$} & \multicolumn{2}{|c|}{$\begin{array}{c}\text { Annual Energy Use Index } \\
\left(\mathrm{kwh} / \mathrm{m}^{2}\right)\end{array}$} & \multirow[b]{2}{*}{$\begin{array}{c}\text { Difference } \\
\%\end{array}$} \\
\hline & $\begin{array}{l}\text { Measured } \\
(\mathbf{2 0 0 2})\end{array}$ & $\begin{array}{c}5 \text {-year billing } \\
\text { average }\end{array}$ & $\begin{array}{l}\text { Measured } \\
(\mathbf{2 0 0 2})\end{array}$ & $\begin{array}{c}\text { 5-year billing } \\
\text { average }\end{array}$ & \\
\hline Owais Al-Qarni & 69809 & 72721 & 186.2 & 194 & $-4 \%$ \\
\hline Al-Humaidi & 40997 & 35559 & 225.3 & 195 & $+15.5 \%$ \\
\hline Al-Bukhari & 139832 & 124213 & 201.5 & 179 & $+12.6 \%$ \\
\hline Abu-Ubaidah & 118393 & 111431 & 93.5 & 88 & $+6.2 \%$ \\
\hline Al-Doha & 173234 & 168603 & 202.9 & 197 & $+3 \%$ \\
\hline & & Average & 181.9 & 171 & $+6.4 \%$ \\
\hline
\end{tabular}

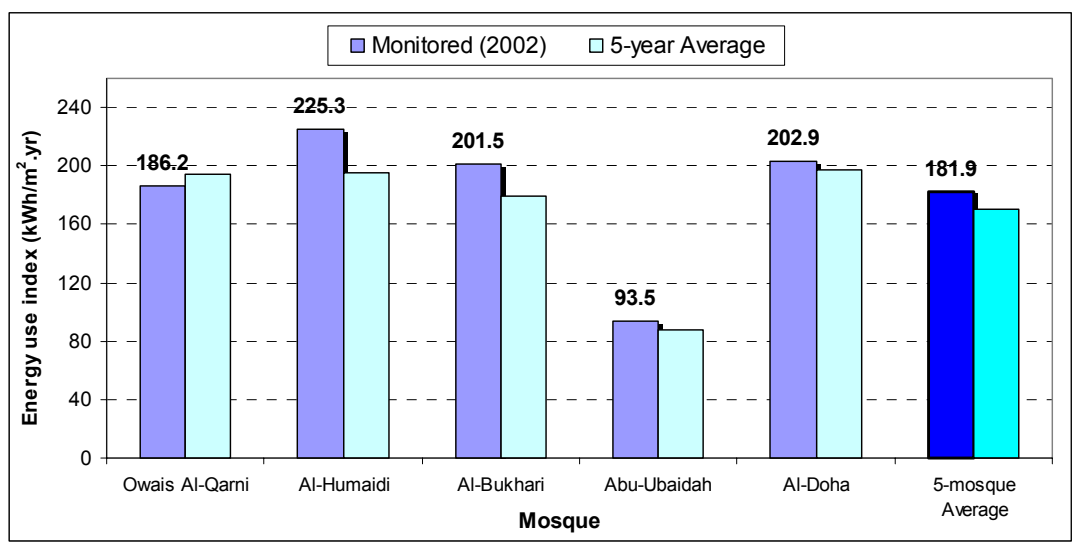

Fig. 6: Monitored annual energy use indices comparisons for the five mosques

\section{Conclusions}

This study presented the analysis of long-term monitored data of energy use for five representative sample mosques. Data acquisition based on 5-minute and 1-hour intervals was used to establish mosque occupancy time periods (OTP), energy use patterns and trends. The monitored data were analyzed and 
compared to a long-term (5-year) average of electric energy utility bills data. Analyses of the segregated energy use data of the investigated mosques revealed that, as expected, the air-conditioning is the most single energy intensive system in the mosque with more magnitude than the case in many other types of buildings in hot-humid climates. Therefore, it requires careful design and operation in order to achieve the required thermal comfort with the lowest energy requirements. The lighting system, although requiring much less energy than $\mathrm{A} / \mathrm{C}$, contributed to steady energy use year round and needs to be designed and operated efficiently. In addition, means should also be provided in the design of mosques to allow for providing natural ventilation for the worshippers during winter and in-between season periods. Additional analyses of the monitored data will be utilized in calibrating an energy simulation program for studying alternative mosque thermal designs and air-conditioning operation strategies. The results of such investigation will be the subject of future work.

\section{Acknowledgment}

This paper is part of project grant no. AT-13-18 funded by King Abdul-Aziz City for Science and Technology (KACST), Saudi Arabia. The financial support of KACST as well as the support and facilities provided by KFUPM are highly appreciated.

\section{References}

[1] (Abdou, A. A., Al-Homoud, M. S. and Budaiwi I. M., Mosque Energy Performance, Part I: Energy Audit and Use Trends Based on the Analysis of Utility Billing Data, King Abdulaziz Journal for Science and Engineering, JKAU: Eng. Sci., vol. 16 no.1, pp. *_* (2005 A.D. 11426 A.H.)

[2] American Society of Heating, Ventilating and Air-Conditioning Engineers, ASHRAE Applications Handbook. Building Energy Monitoring, Atlanta, GA, USA (2003).

[3] http://www.optimumenergy.com/, Optimum Energy Products Ltd, Powerful Solutions. 


\section{أداء الطلقة في المسلجد \\ الجزء الثافي: قيلس و تدقيق لستخدلم الطاقة في المناخ الحار

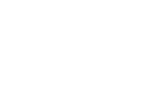

محمد بنسعد لَ حمود، علال عبد المنم عبها إسماعلل بن محمد بليوي

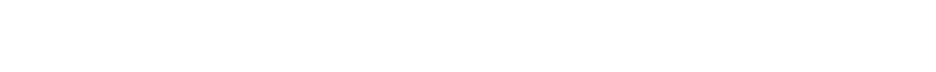

الظهرلن ، المملكة العربية للسعوية المانية

المسخخص: كما هو الحل في مظم المباني في الأقاليم ذات الأحول

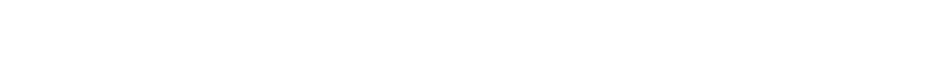

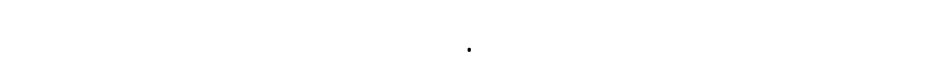

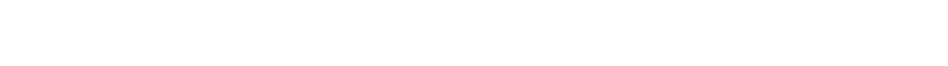

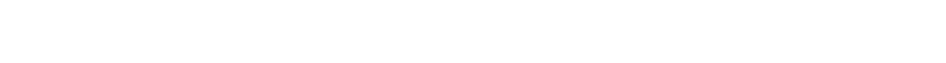
الصلوات الخهس، الأمر الذي ينعكس على ارتفاع الاحتياج الطاقة

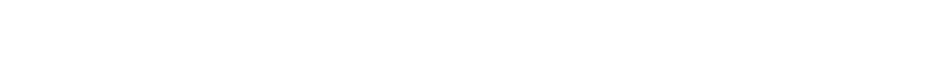
والتفئة الميكانيكية والذي يتزلمن مع أوقات الذروة لاعنية الحتياج الطالة.

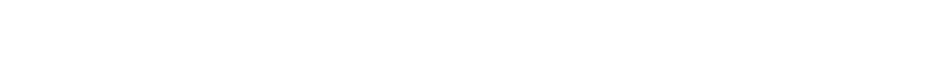

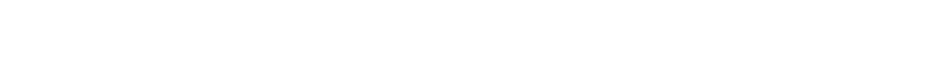

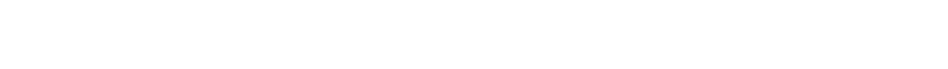
الأداء الحراري للمبن وذلك لدرلماتسة بدائل التصميم الحراري

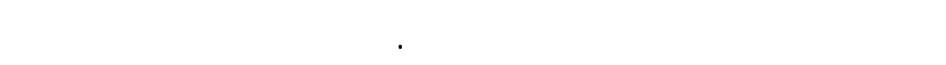


وتدقيق لستخداملت الطاقة في عينة تشتمل على خمسة مسلجد نمونجية

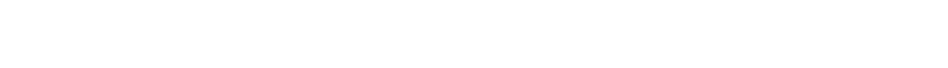

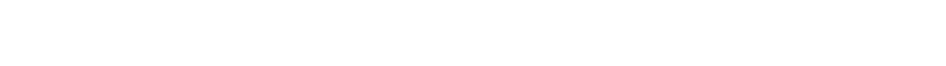
للمسلجد. ويعرض البحث تحليل نتائج القيلس والتدقيق للستخدلملت الطاقة في المسلجد في المناخ الحار الرطب للمطقة للثرقية بالمملكة

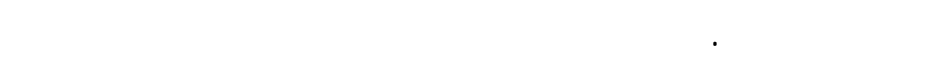
لدرلسة أظمة الطاقة في المسلجد والأداء الحراري الكلي لهاء لهانها ولسترالتيجيلت تشغيلها. 